\title{
Legal Protection Against Banks As A New Creditural Candidate In Take Over Credit Process
}

\author{
Himawan Sutanto \\ Program Studi Magister Kenotariatan \\ Pasca Sarjana Fakultas Hukum Universitas Brawijaya \\ Jl. MT. Haryono 169 Malang 65145, Telp (0341) 553898 Fax (0341) 566505 \\ Email:kukirakami@gmail.com \\ Hanif Nur Widhiyanti \\ Program Studi Magister Kenotariatan \\ Pasca Sarjana Fakultas Hukum Universitas Brawijaya \\ Jl. MT. Haryono 169 Malang 65145, Telp (0341) 553898 Fax (0341) 566505 \\ Email:- \\ Istislam \\ Program Studi Magister Kenotariatan \\ Pasca Sarjana Fakultas Hukum Universitas Brawijaya \\ Jl. MT. Haryono 169 Malang 65145, Telp (0341) 553898 Fax (0341) 566505 \\ Email:-
}

\begin{abstract}
This research journal discusses legal issues relating legal protection of the bank as a prospective new creditor in the process of taking over credit. Where there is no certainty of legal relationship between new creditor candidates with debtor. The Bank as a prospective new creditor can not ensure the release of roya letter on the same day as the binding, so there is no certainty of guarantee status. Bank as a potential creditor becomes a vulnerable party at risk of loss. This study aims to determine and analyze the presence or absence of legal relationship between the bank as a new creditor candidate with the debtor and to know the form of legal protection against the bank as a new creditor candidate in the process of taking over credit that is not in accordance with applicable rules. The research method used by the author is the approach of legislation (statute approach) and case approach (case approach).The absence of a strong legal relationship between the bank as a prospective new creditor with the debtor in the outstanding redemption process, where there is no guarantee of the issuance of the roya letter on the same day during the binding process, in the absence of kepsatian regarding the status of the guarantee, the bank becomes a risky party suffered losses so that the need for a form of legal protection in a preventive and repressive.
\end{abstract}

Key Words: Legal Protection, Creditor Candidate, Over Take Credit.

\section{INTRODUCTION}

Bank is the core of the financial system for each country. The Bank is a financial institution that places companies, government agencies and private and private sectors to save funds. Through lending activities and various services provided, the bank serves the financing needs and payment system mechanism for all sectors of the economy. The Bank functions as 
intermediary parties which surplus of funds and lack of funds, also serving the financing needs and launching a payment system mechanism for all sectors of the community economy.

Such conditions, making the bank as an institution that relies on the trust of the public, the government should be trying to protect the community as a client of agency actions or unscrupulous employees of the bank is not responsible for and undermine public trust. ${ }^{1}$ The task of banking institutions are set up and maintain rupiah stability as well as educate the public to understand the importance of saving in addition, it also helps the government in provision of funds by absorbing all forms of funds that exist in the society.

"Bank is a business entity that collects funds from the public in the form of savings and distributes it to the community in the form of credit and / or other forms in order to improve the standard of living of many people"

Provision of self credit is an activity that contains high risk, so banks are required to always uphold the principles of prudence. Besides, the bank also determines the strategy by competing to provide the best possible service and as much as possible to the prospective customers. This is done so that the customers are interested and do not move to another bank so that the bank is able to obtain maximum benefits from its function in providing credit and the bank will increasingly gain trust from the community (customers).

Regarding the existence of financial institutions in conducting their business activities, all financial institutions are required to apply the precautionary principles mentioned above in conducting their business activities. A manifestation of apply the prudential principles, by enacting the fundamentals of credit granting. The Principle (The five C's of Credit Analysis) Is the basic of Credit, ie: ${ }^{2}$

\section{a. Character}

Assessment of customer (debtor) where it is seen businesses the ability to control the future prospects of the business, production and marketing.

\section{b. Capacity (kemampuan)}

Assessment of customer (debtor) where it is seen businesses the ability to control the future prospects of the business, production and marketing.

\section{c. Capital (modal)}

Bank credit is generally an additional capital. The customer (debtor) must have initial capital depending on the type of business activity. But usually large capital wal minimum of 20 percent of the total funds needed.

1 Muhammad Djumhana.(2006). Hukum Perbankan di Indonesia, Bandung : Citra Aditya Bakti, p. 337 2 Budi Untung.(2000). Kredit Perbankan di Indonesia, Yogyakarta: Andi, p. 3 


\section{d. Collateral}

Guarantee is one element of the credit agreement, a guarantee is necessary to provide confidence in the bank that the borrower is able to repay the loan in accordance with the agreement. Therefore the amount of guarantee in the credit agreement is at least 100 percent of the credit score.

e. Condition of economy (kondisi perekonomian/prospek usaha debitur)

This assessment takes precedence on the circumstances of political, social, economic, and cultural influence economic circumstances within a certain time. The state of the economy here is the country's economy, the customer (debtor), as well as the state of the economy creditor bank.

In terms of lending, banks are often faced with the problem of taking credit, which in the banking world itself is known as credit take over. Take over credit alone has not been firmly stated in the form of defines or concepts in Law Number 10 of 1998 concerning Amendments to Law Number 7 of 1992 concerning Banking. In the case of credit take-over, this activity is regulated in the Bank Indonesia Regulation Number 18/16 / Pbi / 2016 Concerning Loan Value Ratios for Property Loans, Financing To Value Ratios for Property Financing, and Advances for Motor Vehicle Loans or Financing. In Article 13 number (1) only mentioned what matters need to be carried out by the bank, in this article it does not explicitly mention the existence of a credit take-over mechanism.

Although Article 2 states "Further provisions regarding the granting of KP or PP by taking over or taking KP or PP from another Bank are regulated in a Bank Indonesia Circular." However, after that, if we refer to Bank Indonesia Circular No. 18/19 / DKMP, once again there is no clear mechanism regarding the actions of banks in the process of taking credit. The circular letter is only found in CHAPTER IV, letter B number 3, that "The mechanism of taking over Credit or Take over as referred to in number 1 and number 2 refers to the provisions issued by the competent authority." The authority here is a bank.

This is where the author considers that there are still weaknesses in terms of regulatory legality regarding the credit take-over process. Continuing problems, in this case the SKMHT guarantee deed and binding certificate are made before the letter is confirmed to be issued on the same day, should ensure legal certainty, the Notary must sign a financing / credit agreement and SKMHT, after the issuance of the roya letter and original guarantee certificate the new Underwriting Right will be charged. In the SKMHT deed and the APHT deed there are promises and if the Notary uses SKMHT before the date of the roya letter is confirmed to 
be issued on the same day, there will be a repayment of the Underwriting Right.

At the time of making SKMHT and Deed of Underwriting Rights, there must be confidence in the Notary or PPAT concerned that the Underwriting Right giver has the authority to carry out legal actions against the Underwriting Right object charged, even though the certainty regarding the ownership is only required at the time of granting the Underwriting Right it is registered. ${ }^{3}$

Indeed, the Underwriting Right Provider does not have the authority to authorize the new Underwriting Right, because Article 11 paragraph (2) point g of the Underwriting Right Act No. 4 of 1996 states that there are promises in the Deed of Underwriting Rights including promises that the Underwriting Right Provider will not waive his right to the Underwriting Right object without prior written approval from the Underwriting Right Holder (in this case the bank), in which the written evidence is in the form of proof of repayment of debt and letter of credit.

In terms of authority, as one of the legal requirements of the agreement according to Article 1320 of the Civil Code, the giver of the Underwriting Right is not yet valid to authorize the imposition of a new Underwriting Right without the proof of repayment or roya letter from the Underwriting Right Holder, so that the validity of the deed made by the Notary can be questioned.

Moreover, if one of the parties to the deed has bad faith. This is actually a dilemma for Notaries, on the one hand as a Bank Notary partner, has built trust between the Bank and Notary, on the other hand there is a feeling of concern that the Notary will lose his client. Even so, the Notary as a General Officer must not, must prioritize the principle of prudence and make the principle of prudence the main principle for ensuring legal certainty and protection for the parties in the deed he made and also for the protection of the law for himself.

Based on the background stated above, the formulation of the problem in this journal writing is how the legal relationship between banks as prospective new creditors and debtors regarding outstanding repayment in the process of take over credit? and how accordance with the applicable rules?

\section{METHOD}

The research method used in this journal writing is normative juridical research, which

Remy Sjahdeini.(1999). Hak Tanggungan Asas-asas Ketentuan-ketentuan Pokok dan Masalah yang Dihadapi oleh Perbankan, Bandung: Alumni, p.217 
is often recited in the past, and the doctrine that is often used by law firms that are contracted with problems that will be examined in this day only legal protection against banks as potential creditors. new in the process of take over credit. The research that is examined by the author is about the legal relationship that occurs between banks as prospective new creditors and debtors in the process of taking credit. Besides that, there is also a form of legal protection for banks as prospective new creditors in the credit take-over process that is not in accordance with the applicable rules.

The approach used is the statute approach and the case approach. This method is to find out that all of us have to analyze the laws and regulations that affect the legal protection of banks as prospective new creditors in the process of credit overtake, so that they can be found resolving this problem and can never be done or not. uncertainty in what happened in the situation.

\section{ANALYSIS AND DISCUSSION}

\section{Legal Relations Between Banks As Prospective New Creditors And Debtors Regarding Outstanding Repayment In The Take Over Credit Process}

As for the process of credit transfer, the role of the bank as a candidate for new creditors as the party that takes over credit is to carry out the following stages : ${ }^{4}$

1. Credit Officer, who functions as the party in charge of analyzing credit for credit requests brought by Marketing. Credit Officer in analyzing credit is not only about the character of the customer but also conducts business verification whether the prospective debtor's business is feasible to be financed, and verifies the guarantee to find out whether the guarantee can be used as a substitute if the debtor defaults.

2. Credit Administration functions as a party that verifies the completeness of loan data from prospective customers before being submitted to the Credit Officer for a survey of prospective customers. Another function of credit administration is as a legal credit that plays a role in examining all matters relating to the binding of credit agreements both documents made by a notary (deed of credit agreement, fiducia, Power of Attorney to Charge Underwriting and Deed of Underwriting Rights etc.) and data others related to legal or legal fields. Data that is ready and complete can be submitted to the Credit Officer for the survey process.

4 Nurfauzia.(2013). Mekanisme Peralihan (take over) Kredit Perbankan di Indonesia, Jurnal Lex Specialis Edisi Khusus, accessed $\quad$ on $\quad 10^{\text {th }} \quad 2018$, http://jih.unbari.ac.id/index.php/LEX_SPECIALIST/article/view/66. 
3. Credit marketing serves as the spearhead of banks in finding customers / prospective borrowers. Not all prospective customers brought by marketing can be approved by the bank in providing credit facilities, because the decision to provide fixed credit must be assessed objectively from the survey conducted by the Credit Officer and the completeness of the data that supports the provision of credit. If the conditions specified above are fulfilled by the prospective debtor, then the prospective debtor is asked to fill in the Credit Application Form containing the debtor's identity, the requested credit limit, the purpose of the credit usage, the type of guarantee to be submitted and the party's signature the debtor and the bank offering. If the Credit Application form has been filled out and submitted to the bank, the bank will do the following:

a. BI Checking The first step in tracking the character of the debtor is through BI checking that is obtained from the Debtor Information System. This debtor Information System at Bank Indonesia contains data on all customers of financial institutions in Indonesia (as long as the data is registered / recorded in the debtor Information System by the relevant agency) regarding the customer's identity, loan amount, bank lender and collectability of the customer. From these data we can find out where the prospective customer position will be taken over, whether in the status of current collectibility, in special attention, substandard, doubtful or stalled. in this case the bank only gives credit to prospective customers who have smooth collectibility, and will immediately refuse if their collectability status is smooth. Often when prospective customers come to the bank, they try to cover up whether they have or are in debt to another party or not. The customer does not understand that the bank has data in the Debtor Information System regarding the customer's track record in terms of credit, so that the bank can understand whether the pro spective debtor is lying or not when they try to cover up their credit background.

b. Analyze the completeness of the documents, Prospective debtors who have filled out the Credit Application form must include the initial data (can be submitted to marketing to be forwarded to the credit administration) for the benefit of administrative data and requirements for conducting a Credit Officer survey. The data includes a photocopy of the identity of the prospective debtor (Identity Card of the debtor and spouse both husband and wife and guarantor if any, family card, marriage certificate etc. which has not expired). If the requirements are considered complete according to procedures and conditions set by the bank. Furthermore, the 
Credit Administration section provides data to the Credit Officer to be followed up with a survey. If there is a lack of data in the administration of data, then the credit administration will make a lack of data checklist that contains data deficiencies and completion date targets signed by Marketing, Credit Administration and Unit Leaders. This checklist will be submitted to the Credit Officer along with the complete data to be followed up with a survey to prospective customers. Credit Officer has the right to refuse to conduct customer surveys if the data submitted to Credit Officer is lacking or incomplete. If this happens, marketing must inform prospective borrowers to immediately complete the data shortage.

4. Survey Credit Officer. Condact a survey if all primary data is sufficient as a basis for condacting a survey. The aims to determine the fasibility and assessment of the character, ability, capital,collateral, conditions of prospect of the debitor's business known as the $5 \mathrm{C}$ analysis principle. The series of activities in the survey can be categorized into 3 parts, those are :

a. Crosscheck data (debtor interview) In this section, the Credit Officer conducts interviews with prospective customers accompanied by supplementary data collection which is deemed necessary to investigate the correctness of the data between data submitted by prospective borrowers in writing to the bank with actual data. An example of this activity is to ensure that the wife of the prospective debtor also knows that her husband / partner is in debt to the bank in relation to this property. other people.

b. Trade checking (survey usaha) Trade checking is a method used to examine the business of the prospective customer in question by conducting short interviews with people who have business relationships with prospective borrowers. The purpose of this activity is to find out objectively how customers interact with the environment and related parties related to the business of prospective borrowers. The parties referred to include neighbors, suppliers of goods, distributors, and can also interview buyers who happen to be conducting transactions with prospective customers. This activity is also balanced by looking at the actual condition of the business concerned whether the written data submitted to the bank is in accordance with the facts in the field regarding turnover, business development, financial analysis and the net benefits derived from this business. 
c. Appraisal survey The existence of a guarantee is very important when the debtor experiences default in installments. The purpose of this assessment is to estimate whether when the debtor defaults, the guarantee can cover credit after the auction is conducted for the bank's interest. Assessment of the value of collateral must be done carefully and objectively as possible. This Appraisal or Appraisal consists of determining the market price of a guarantee that will be provided by the prospective customer to guarantee the proposed credit and the determination of the price of the bank's assessment to determine how much minimum value can be sold quickly in the community and to calculate how much the maximum loan can be given to prospective customers. The determination of the market price (market) of the object of the guarantee must not only be determined from the value stated in the SPPT PBB, but seen factually and the reality that exists in the community. Determination of the value can be done by asking the community about the fair value of the guarantee, and can also ask in the relevant village office. This process is carried out as the basis of the Credit Officer verification if at any time in the event of default or at least an indication of violation is found by the Internal Control team (audit), the Credit Officer can prove to the relevant party that the Credit Officer has carried out objective assessment and analysis tasks and based on written facts and facts that occur in the field. In addition to the above three activities, there are special things that must be done by the Credit Officer in the series of survey activities related to the credit transfer process, those are:

1) Make a credit guarantee check. Check guarantee is a means provided by the National Land Agency for immovable objects and the Fiducia Registration Office for movable objects that are registered to find out who these guarantees are covered. One of the main conditions in the guarantee check is to submit original proof of ownership for review. Especially for immovable objects, the guarantee check for take over facilities cannot be carried out by physical check certificate at the National Land Agency, because the certificate position is still at the place of the initial creditor, and may not be issued even at the request of the debtor as long as the credit has not been repaid. check the peek stating that the guarantee is insured only to the original creditor, then the analysis process can proceed.

2) Check the remaining outstanding loans in the original bank. Marketing and Credit Officers must find out how much of the remaining outstanding credit is 
in the initial creditor and must request a credit transfer and the existing payment slip from the original creditor. This is done to find out how much funds are actually needed for the credit transfer process. Another reason for checking credit outstanding is to prevent debtors from committing fraud against the related bank.

3) Ensuring credit objectives in addition to credit transfer facilities. The granting of credit transfer facilities is not only to repay prospective customers' credit but also to provide additional funds in the form of working capital and investment. Credit transfers that are only intended to pay off credit at the original creditors and to finance the business other than what has been written in the Credit Application and credit recommendations are not permitted by the relevant bank.

5. Making Credit Recommendations. After conducting the survey, the Credit Officer makes a recommendation for credit submission to the Area office (branch office) which contains data analysis on what has been investigated in the survey activity. Recommendations for granting a credit decision that is a conclusion from the results of the analysis and evaluation that has been carried out by the Credit Officer must be submitted in writing to the credit committee, namely the official who has BWMK (Limit of Credit Giving Authority) or Credit Breaker authorized to decide according to the credit ceiling . Fill recommendations into one unit by granting credit decisions. Recommendations must clearly outline weaknesses and strengths that will affect the ability of debtors to repay credit, both first way out / repayment capacity and second way out. What is meant by first way out or repayment capacity for credit repayment is the ability of the debtor to repay the loan with funds originating from business results financed by credit and reflected in the debtor's cash flow. Whereas the understanding of second way out credit repayment is the ability of the debtor to repay the credit originating from the disbursement or liquidation of collateral. Credit application proposals that have been approved by the branch office must be signed by Marketing, Credit Officer, Senior Credit Officer and Area manager. The credit recommendation note contains data from the survey containing the debtor's identity, type of business, background, and business activities, facilities requested by the debtor, collateral data, purpose of using funds, financial analysis and relationships with banks. After this 
recommendation is signed, a Credit Decree is made stating that the request for credit has been approved by the Bank.

6. Credit agreement process, If the credit application is refused, then the credit administration department will contact the prospective debtor and notify that credit cannot be given. If the loan application is approved, then the debtor is asked to come to the bank related to the credit agreement process and the guarantee agreement. The process of this contract must be attended by unit leaders, credit administration department, partner notaries and prospective borrowers along with their wives / husbands and guarantor if any. The credit agreement process contains activities in the form of:

a. Credit offer that contains the approved total ceiling, fees, insurance premiums, schedule and monthly installments and costs incurred by the debtor. Debtor candidates who agree to the offer will sign the credit offer form.

b. The signing of the statement of debiting the account and the statement of supervision of the guarantee by the bank.

c. Signing of the credit agreement deed. Credit used for credit transfer, must be expressly stated in the credit agreement deed stating that partial credit is used for credit transfer facilities at the place of origin. The contents of the credit agreement are: the identity of the parties, a clause stating that the debtor submits a loan application and that the creditor provides credit to the debtor, a clause regarding the loan amount, a clause stating the purpose of credit usage (in this case the purpose of credit transfer), then regarding time period, clauses regarding interest, fees and fines, clauses on how to take credit, clauses on how to pay credit, clauses regarding negligence and additional fines, guarantee challenge clauses, insurance clauses, clauses about other costs, clauses regarding emptying, clause of domicile.

7. The mechanism of debt transfer (take over) the debtor is required to make a statement of ability to replace any losses suffered by the bank if in the course of the credit transfer process, the debtor cancels the loan application and or the bank sees no signs of bad intentions from prospective customers. concerned. 8. The process of binding guarantees, the next process is the binding of guarantees that must be done before a notary / PPAT bank partner. In the event of a credit transfer, the certificate is still in the power of the original bank or financial institution and physical checks cannot yet be made on the certificate at the National Land Agency so that the bank's position cannot know for certain who are the holders of the mortgage rights. The bank is 
obliged to work with the notary and the National Land Agency to check peeping (this activity is not an official BPN activity, but it happens in the field which functions almost the same as a physical check that is to find out the certificate with a certain number whether it is burdened by mortgage or not. Physical checks are found on the need or not of the original certificate presented at the National Land Agency and check peeping is not an official activity of the National Land Agency.

8. Credit disbursement process, After all the deeds and letters and all operational requirements have been agreed upon and signed by the debtor, the next process is credit disbursement, namely the provision of a certain amount of money in accordance with the approved credit ceiling to the debtor, in this case the relevant bank usually does not directly provide a number of credit plafonds requested, but only a part of the total amount is outstanding for payment in the initial creditor. After the payment is made and the payment slip and collateral move from one bank to another. It is intended that the debtor immediately repay / pay the credit on the same day so that there is no time lag (days) between the granting of credit and the handover of the guarantee.

Guarantee transfer process, Immediately after disbursement of credit, the debtor is required to use part of the money to repay the credit at the bank or financial institution of origin as originally required in the credit agreement. The debtor accompanied by marketing comes to the bank or financial institution of origin to make credit payments according to outstanding / outstanding debit at the place of origin.

Based on the data obtained from the research that has been done, it can be said that the provision of credit using the mechanism of credit transfer (take over) has a procedure or mechanism that is different from the provision of credit in general. The provision of credit with the mechanism of credit transfer (take over) is only intended for prospective borrowers who when given credit as a status of a customer from other creditors and have a smooth collectability status. The status of current collectability means that the debtor, as long as he is a customer in the initial creditor, has a credit track record that has a smooth / satisfactory journey, there is no arrears in principal installments.

From the mechanism of legal relations that occur in the process of taking over credit above, actually the legal relationship between banks as prospective creditors is quite clear, but in practice in the field, banks as prospective new creditors are considered to be less careful in carrying out these legal actions. Banks as prospective new creditors actually do not have or 
have not found any legal relationship that should exist first so that the bank as a prospective new creditor can do the proper legal actions.

However, in this problem it was found that there was no strong legal relationship between the bank as a prospective new creditor and debtor. Like among others, banks as prospective new creditors in the credit take-over process cannot ensure that the issuance of a letter of credit can appear on the same day as the creation of a credit agreement between banks as prospective new creditors and customers. This concerns the status of the guarantee that will be used by the bank as a prospective new creditor as the guarantor of the debtor. Because if the roya letter cannot be ascertained to come out on the same day during the binding process, this of course raises an uncertainty regarding the status of the collateral object.

Furthemore, it is feared that the bank as the party who takes over the debt is vulnerable to the risk of the actions of debtors who may have bad faith in the credit take-over process that has been carried out.

\section{Legal Protection for Banks as Prospective New Creditors in the Take Over Credit Process}

Legal protection is an effort to protect legal subjects in the form referred to through the regulation of legal instruments contained in laws or other regulations, both preventive and repressive. Legal protection as an illustration of the legal function, namely the concept of law that can provide justice, order, certainty, usefulness and peace.

Legal protection is the protection of dignity and dignity as well as the recognition of human rights possessed by legal subjects in the rule of law based on the provisions of the law in force in the country to prevent abuse. Legal protection is generally in the form of a written regulation, so that its nature is more binding and will result in sanctions that must be imposed on those who violate it. ${ }^{5}$

In terms of preventive legal protection, the Bank is required to implement Risk Management. In this regard, the principles of Risk Management which will be adopted and applied to Indonesian banks are directed in line with recommendations issued by the Bank for International Settlements through the Basel Committee on Banking Supervision.

These principles are basically a standard for the banking world to be able to operate more carefully in the scope of the rapid development of business activities and banking 
operations today. Through the implementation of Risk Management, the Bank is expected to be able to measure and control the risks faced in carrying out its business activities better. Furthermore, the implementation of Risk Management conducted by banks will support the effectiveness of the Risk-based Bank supervision framework carried out by the Financial Services Authority. The definition of the principle of prudence itself is the principle of risk control through the application of legislation and the provisions that apply consistently. The purpose of the application of the precautionary principle is to maintain the security, health and stability of the banking system of the laws and regulations that apply consistently.

Whereas in the elucidation of Article 4 paragraph 1 of Act Number 24 of 1999 concerning Foreign Exchange Flows and the Exchange Rate System, it is stated that the precautionary principle is one of the efforts to minimize business risks in managing banks, both through provisions stipulated by Bank Indonesia and the bank's internal provisions. In Act Number 23 of 1999 concerning Bank Indonesia Article 25 paragraph 1 regulates the authority of Bank Indonesia to regulate prudential principles for bank businesses by stating that "in order to carry out the task of regulating banks, Bank Indonesia has the authority to stipulate banking provisions that contains the precautionary principle.

Besides that, more clearly about the preventive form of legal protection against banks, primarily as an effort to prevent losses or prevent the occurrence of risks to actions or business activities carried out by the bank, a Financial Services Authority Regulation which is more detailed addressing the attitude or action must be issued. prevention that needs to be carried out by banks in order to carry out their business activities in the credit sector, namely the issuance of the Regulation of the Financial Services Authority Number 42 / Pojk.03/2017 concerning the Obligation of Preparation and Implementation of Bank Credit or Financing Policies for Commercial Banks.

While the form of repressive protection According to Philip M. Hadjon that the legal protection is repressive is a legal protection obtained by way of taking a general court or amicable method. ${ }^{6}$ This repressive legal protection aims to solve problems or disputes that arise if there is a violation of legal norms in the legislation.

Repressive legal protection aims to resolve a dispute that can cause a loss. This protection is used as a step towards the possibility of the risk of loss from business activities carried out by the bank. In this case, the bank will become a new candidate for creditors in the credit take-over process.

6 Philipuss M. Hadjon.(2007). Perlindungan Hukum bagi Rakyat Indonesia, Surabaya: Bina Ilmu, p.2 
Legal protection for prospective new creditors in the take over process has a wider impact due to the legal later if there is a knowledge that the debtor has no intention. For banking institutions in general, it is expected to always apply the principle of prudence in every credit provision in this case, especially the credit take-over process. However, if in the future it is found that the debtor has bad faith or disappeared. So it needs a settlement through the judicial route to be expected to be able to resolve the dispute or problem.

This is certainly linked to the illegal acts committed by the debtor. In Article 1365 of the Civil Code, it is stated that every act that violates a law that brings loss to another person, obliges the person who due to wrong to issue the loss, compensates for the loss. Because here there is a causal relationship where the bank as a prospective new creditor will not pay off the outstanding debtor if the debtor does not want the process.

So that later it is expected that with the existence of this court, it can minimize the losses experienced by the bank in this case is the bank that acts as a prospective creditor in the process of credit takeover. So that through a court decision, the bank can carry out executions of debtors with bad intentions. So that the bank as a potential creditor in the credit take-over process becomes a party that is not harmed.

\section{CONCLUSION}

The legal relationship between banks as prospective new creditors and debtors regarding the outstanding repayment in the credit take-over process according to the author already exists, but in this case the bank was felt too rushed to pay off outstanding or remaining debt held by the debtor against the initial creditor. The bank is impressed to do legal actions in the form of submission of remaining outstanding outstanding money where there is no guarantee that roya can be issued on the same day as the credit binding. So it cannot be binding in the form of a new credit agreement because there is no guarantee and certainty regarding the guarantee status. So that the bank becomes a party at risk of loss.

The form of legal protection for banks as prospective new creditors in the credit takeover process that is not in accordance with the applicable rules is carried out in a preventive and repressive manner. Where preventively involves the compliance of banks as prospective creditors in the process of taking over the provisions of the legislation, namely the principle of prudential banking principles or the principle of prudential banking. While the repressive method is by way of settling disputes or problems if in the future the debtor has a bad faith through the judicial rout 


\section{BIBLIOGRAPHY}

\section{Books}

Budi Untung.(2000). Kredit Perbankan di Indonesia, Yogyakarta: Andi.

Daeng Naja.(2005). Hukum Kredit dan Bank Garansi, Bandung: Citra Aditya Bakti.

Muhammad Djumhana.(2006). Hukum Perbankan di Indonesia, Bandung: Citra Aditya Bakti.

Philipuss M. Hadjon.(2007). Perlindungan Hukum bagi Rakyat Indonesia, Surabaya: Bina Ilmu.

Remy Sjahdeini.(1999). Hak Tanggungan Asas-asas Ketentuan-ketentuan Pokok dan Masalah yang Dihadapi oleh Perbankan, Bandung: Alumni.

\section{Journals}

Nurfauzia, "Mekanisme Peralihan (take over) Kredit Perbankan di Indonesia”, Jurnal Lex Specialis Edisi Khusus Agustus (Agustus 2013): 91, accessed on May $10^{\text {th }}$ 2018,http://jih.unbari.ac.id/index.php/article/view/66

\section{Legislation}

Undang-Undang Dasar Negara Republik Indonesia Tahun 1945

Kitab Undang-Undang Hukum Perdata.

Undang-Undang Republik Indonesia Nomor 10 Tahun 1998 Tentang Perubahan Atas Undang-Undang Nomor 7 Tahun 1992 Tentang Perbankan (Lembaran Negara Republik Indonesia Tahun 1998 Nomor 182);

Undang-Undang Republik Indonesia Nomor 4 Tahun 1996 Tentang Hak Tanggungan Atas Tanah Beserta Benda-Benda Yang Berkaitan Dengan Tanah (Lembaran Negara Republik Indonesia Tahun 1996 Nomor 42)

Peraturan Bank Indonesia Nomor 18/16/Pbi/2016 Tentang Rasio Loan To Value Untuk Kredit Properti, Rasio Financing To Value Untuk Pembiayaan Properti, Dan Uang Muka Untuk Kredit Atau Pembiayaan Kendaraan Bermotor. 